\title{
Quaderni
}

QUADERNI Communication, technologies, pouvoir

Translating stem cells to the clinic: scientific societies and the making of regenerative medecine

Transposer les cellules souches en clinique : sociétés savantes et structuration de la médecine régénérative

\section{Alessandro Blasimme}

\section{(2) OpenEdition}

Journals

\section{Electronic version}

URL: http://journals.openedition.org/quaderni/704

DOI: 10.4000 /quaderni.704

ISSN: 2105-2956

\section{Publisher}

Les éditions de la Maison des sciences de l'Homme

Printed version

Date of publication: 5 June 2013

Number of pages: $29-44$

\section{Electronic reference}

Alessandro Blasimme, «Translating stem cells to the clinic: scientific societies and the making of regenerative medecine », Quaderni [Online], 81 | Printemps 2013, Online since 05 June 2015, connection on 19 April 2019. URL : http://journals.openedition.org/quaderni/704 ; DOI : 10.4000/ quaderni.704 


\section{$D$ ossier}

\section{Translating stem cells to the clinic : scientific societies and the making of regenerative medecine}

\section{Alessandro Blasimme}

Postdoctoral fellow at Inserm, UMR U 1027, Université de Toulouse Paul Sabatier-Toulouse III
An aura of controversy has always accompanied the development of biotechnology and its extension to a number of scientific and medical domains up to present days. As a matter of fact, as highlighted also by other contributors to this volume $^{1,2}$, the way in which biotechnology is regulated calls into question the very essence of liberal democratic science policy and thus urges an analytical effort at clarifying the foundations of governance options in this domain and the values they embed.

With this objective in mind, one cannot fail to acknowledge that stem cell biology epitomizes this common trait of controversy in biotechnological progress: starting from the late Nineties, the stem cell community was caught in the midst of a planetary political battle over the ethical legitimacy of stem cell research, especially as it concerned the derivation of pluripotent and multipotent stem cells from human embryos and fetuses. The latter's moral status was hotly debated and required landmark political and judicial decisions that, differently in different countries, fixed the limits and the conditions for the use of early human conceptuses for scientific and clinical research ${ }^{3}$. However, the debate about the governance of stem cell research did not cease to be contentious after the emergence of specific normative arrangements to regulate the use of embryos and fetuses. Quite to the contrary, while the philosophical debate on the moral status of early human life is still open ${ }^{4}$, scientists and commentators raise new concerns about the way existing regulations impinge on the ability of stem cell science to deliver its promised clinical applications. A great deal 
of current debates on stem cell research thus revolves around the governance of the so-called scientific translation of stem cell research into usable regenerative medicine ${ }^{5}$. The notion of translational science designates a phase in the development of scientific innovation (between basic research and its clinical application), as well as a modality of scientific inquiry aimed at providing the scientific rationale to include safe and effective new treatments into the standard of health care. Contrary to what might be assumed to be the case, however, the epistemic and regulatory foundations of translational science are not clearly established: in fact, disagreement and even conflict insist on the ethical assessment, the scientific justification, the political regulation and the commercial aspects of biotechnological innovation in the field of regenerative medicine, as well as in other areas of biomedical innovation.

This paper sets out to show that different and indeed antagonistic models of clinical translation are emerging in the realm of cellbased regenerative medicine embodying rather different ontological, epistemic, ethical and regulatory assumptions. In this article I will thus illustrate two prominent bodies of professional guidance issued by two different scientific societies active in the field of stem cell-based regenerative medicine: the International Society for Stem Cell Research (ISSCR) and the International Cellular Medicine Society (ICMS). These guidelines offer strikingly diverging accounts of how stem cells should be translated into therapies for patients, thus demonstrating the existence of disjunctive framings of clinical translation. Each scientific society enacts specific discursive strategies to project legitimacy onto their respective framings of regenerative medicine: both mobilize - and to a good extent, construct - at the same time ad hoc epistemic and professional norms to corroborate their claims as to how the translation of stem cell science into regenerative medicine is supposed to take place and to be regulated. In this confrontation the co-production of science and social $\operatorname{order}^{6}$ comes to be seen in bold relief, as evidentiary standards, medical categories, regulatory arrangements and professional liability become embedded in translational models of regenerative medicine.

In what follows, this paper describes complex strategies to attain at the same time professional cohesion and public trust in the scientific activities of a given group of scientists. In this perspective, looking at the different routes towards standardization that are being mobilized by professional scientific societies provides the opportunity for a deeper understanding of the very constitution of translational options in regenerative medicine.

\section{Regenerative medicine: work in progress}

Before devoting our attention to reconstructing how the ISSCR and the ICMS imagine stem cell-based regenerative medicine and its translation from laboratories to clinical wards, it is advisable to clarify how the notion of regenerative medicine is to be understood. The following definition may thus be useful to this aim, as it captures the large semantic latitude of regenerative medicine in a relatively condensed way: 
« Regenerative medicine is an interdisciplinary field of research and clinical applications focused on the repair, replacement or regeneration of cells, tissues or organs to resort impaired function resulting from any cause, including congenital defects, disease, trauma and ageing. It uses a combination of several converging technological approaches, both existing and newly emerging, that moves it beyond traditional transplantation and replacement therapies. The approaches often stimulate and support the body's own self-healing capacity ${ }^{7}$.

Albeit not new, the idea of restoring the impaired functioning of bodily structures through products of biological origin recently re-gained momentum as science proved able to experimentally control the proliferative and differentiative fate of human cells both in vitro and in vivo. Those new manipulative abilities tempt biomedical researchers to probe how stem cells could be harnessed to restore the functionality of diseased human bodies. In truth, the rationale for taking this therapeutic direction is not entirely original ${ }^{8}$. Bone marrow grafts for patients affected by hematological cancer represent the first stem cell therapy to successfully bridge the gap from the bench to the patient's bedside9. Other familiar examples of regenerative medicine are blood transfusions and organ transplantations: these examples confirm that the human body is already being used as materia medica in contemporary medicine. However, one main difference between these early examples of regenerative medicine and what stem cells might do in terms of bodily regeneration in the imminent future needs to be highlighted. Blood and organs are transferred from one body to another following relatively minor manipulations, apart from those handling procedures (like refrigeration for example) that are necessary to keep them useable while being transported from the donor to another recipient body. The current idea of regenerative medicine, however, generally means more than this from a technical point of view. In regenerative medicine, the displacement of human cells from one body to another (heterologous treatment) or the re-implantation of cells extracted from the same patient (autologous treatment), is generally mediated by molecular-level manipulations that transform a given body "part" into the desired kind of entity that the receiving patient needs. This manipulation can be both qualitative and quantitative: techniques that are typically used in molecular biology laboratories can now be translated to the clinic to both alter the identity of a given set of stem cells (for example by directing them towards more differentiated phenotypes) or to expand them, thus increasing their number up to the amount necessary for therapeutic use. Furthermore, in recent years, techniques have been developed to reprogram fully differentiated cells to a pluripotent state ${ }^{10}$, from which they can subsequently be driven to any somatic lineage and, in theory, be used for therapy - thus avoiding the ethically contentious destruction of human embryos that was previously needed to obtain pluripotent stem cells ${ }^{11}$.

Schematically, there exist three major modes of activity that can be exploited in cell-based regenerative medicine. Cells injected into a patient, whether they come from the same patient or from a donor, could provide a therapeutic 
function by either: secreting trophic factors and exerting an immunomodualtory activity ${ }^{12}$ (e.g. reducing localized inflammation); replacing a piece of damaged cellular structure with or without the support of biomaterials and synthetic scaffolds $^{13}$ (e.g. in chondrocyte-based cartilage replacement treatment ${ }^{14}$ ); by reconstituting in vivo a cellular structure starting from the injection of stem cells that have the capacity to differentiate in an orchestrated and hierarchical fashion (e.g. neural stem cells for treating the effects of ischemic stroke ${ }^{15}$ ). In all the above cases the cells of origin can be stem cells, progenitors or differentiated cells (as such, or obtained through reprogramming) depending on the technical protocol chosen by the research team.

Arguably, the future of the field crucially depends on the development of safe and effective cell therapies and cell products, and thus relies as much on technical progress as it relies on the emergence of a common governance framework that is able to assure an ethically defensible and scientifically reliable translation of stem cells. The gold standard for the validation of biomedical innovation in Western medicine is the standardized generation of knowledge through clinical trials conducted according to the epistemic principles of evidence-based medicine ${ }^{16}$. As a matter of fact, however, stem cell translation is a global enterprise featuring a number of actors racing to deliver as soon as possible their cellular products and therapies to the market. In this context, different actors have different ideas about how stem cell biology should be translated into regenerative medicine. Alongside technical uncertainties, regulatory gaps and a heterogeneous global legislative framework also affect the development of regenerative medicine, thus leaving the debate open about how public authorities should regulate this process, how patients should be involved and, finally, how this science should be exploited commercially. It is in this scenario that, in recent years, stem cell clinics arose offering stem cell treatments directly to patients, contrary to the advice of large sectors of the scientific community. Stem cell medicine centers are active in the US, in Europe and Central America as well, but most of these clinics are reported to be in Asia (especially in China ${ }^{17}$ ). The typology of injected cellular products ranges from fetusderived cells, to autologous adult stem cells of various origin, employed to treat a variety of conditions including arthritis, fatigue, Parkinson disease, stroke and sometimes cancer. The scientific community has been rather consistent in considering those treatments as scientifically unproven $^{18}$, medically unjustified, and ethically unwarranted, but a market of adult stem cell therapies nevertheless arose.

Some prominent protagonists of this dispute produced guidance documents that demarcate the validity of their own respective framings of stem cell innovation. In the next section, I will reconstruct such effort by reporting about alternative understandings of stem cell innovation by, respectively, the ISSCR and the ICMS. The recent activity of these two scientific societies provides evidence as to the emergence of alternative framings of stem cell innovation in the field of regenerative medicine. In what follows I will thus reconstruct the ontological, epistemic and regulatory commitments that constitute their respective order-making strategies. 
Normalizing the boundaries of stem cell medicine: the epistemic vigilance of the ISSCR

The International Society for Stem Cell Research (ISSCR) is a scientific society established in 2002 to promote the advancement of stem cell research. During the first ten years of its activity the ISSCR has earned international renown for the scientific reputation of its members, who are among the major figures of last decade's advancements in the science of stem cells. In 2008, as the issue of stem cell clinics was gaining headlines in both scientific and popular press, the ISSCR published a set of specific Guidelines for the Clinical Translation of Stem Cells $^{19}$. This document - written by a dedicated multidisciplinary task force ${ }^{20}$ - offers advice as to how to attempt scientifically sound and ethically defensible stem cell clinical translation.

At first, the document establishes a clearcut distinction between responsible clinical translation - assured by voluntary adherence to the guidelines recommendations - and unproven commercial stem cell interventions. As a matter of fact, one of the main purposes of this body of guidance is to reaffirm that stem cell therapies marketed directly to patients before proper clinical validation are scientifically inconsistent and morally dubious. As a matter of fact, in recent years, patients who exhausted other clinical options, or were simply lured by cellular medicine advertised through the Internet, have spent considerable amounts of money for non-validated cell-based interventions, often travelling to distant countries to avoid restrictive regulatory regimes. The ISSCR considers these interventions as possible sources of fraud and exploitation as they are not backed by any " credible scientific rationale, transparency, oversight, or patient protection $»^{21}$, as specified by the Guidelines.

To counteract this phenomenon, the ISSCR guidance vigorously subscribes to the idea that certified scientific knowledge cannot be obtained but through the cherished procedure of peer-reviewing. The latter principle stands as a defining pillar in the edifice set up by these guidelines. As a consequence, ISSCR's guidelines endorse evidence-based clinical trials as the most accredited source of peerreviewed knowledge-making in the clinical field and downplay the reliability of procedures that bypass or avoid them. According to this framing, the clinical translation of stem cells should resemble that of synthetic drugs and therefore take place through the conventional pipeline of knowledge certification of regular clinical trials. In this respect, this framing attempts to normalize $e^{22}$ the clinical development of regenerative medicine and thus to project order onto this emerging field of biomedical innovation. The novelty of stem cell medicine, with its epistemic and ethical uncertainties, is thus tamed through stipulating which modalities of knowledge production and certification are admissible and which are not. The document therefore abides to a modality of knowledge making that Cambrosio and colleagues aptly described as a form of «regulatory objectivity $»^{23}$.

Importantly, the ISSCR guidelines acknowledge a role of regulatory oversight to bioethics committees and, most notably, to governmental 
agencies like the Food and Drug Administration (FDA) in the United States or the European Medicines Agency (EMA) in Europe, thus coupling the epistemic authority of the scientific community with the regulatory power of the State. Further confirmation of these purported alliances can be found in the ISSCR Patient Handbook on Stem Cell Therapy, also published in 2008 and available on the society's website. This document, other than popularizing a few basic notions about the biology of stem cells and their possible medical promises, warned potential patients of stem cell treatments to be watchful when approaching stem cell clinics, especially if the latter failed to show: 1) peer-reviewed replicable preclinical studies, 2) the existence of an Institutional Review Board (IRB) or Ethics Review Board (ERB) assessing the proposed intervention from an ethical standpoint, and 3) the approval of a regional or national regulatory agency. In addition, the handbook alerted patients to be particularly wary of stem cell treatment providers when: patient testimony is the only basis for efficacy and safety claims, the same cells are used to treat a multiplicity of conditions, clear documentation is missing as to the source of the cells or nature of the treatment, and risks are said to be absent.

The pragmatic standardization of knowledgeproduction through clinical trials, the ethical oversight by dedicated bioethics committees and the regulatory oversight of public authorities are thus also construed, respectively, as the epistemic, ethical and regulatory firewalls to protect patient from fraudulent commercialization of unproven treatments.
ISSCR does not however deny that medical innovation can, and indeed does occur also outside clinical trials. The guidelines therefore advance the notion of "Stem Cell Medical Innovation". This notion closely resembles the idea of compassionate use of still not fully proven therapies for individual patients, as it demarcates the boundary between acceptable administration of unproven stem cell therapies to a very small number of patients and unacceptable unproven stem cell treatments marketed to an indefinite amount of patients. Again, rigorous peer-review of the scientific rationale for attempting "Stem Cell Medical Innovation" outside the framework of clinical trials, and ethical oversight by accredited authorities is the defining criterion for such modality of clinical innovation.

We can therefore conclude that this framing of stem cell translation allows science, bioethics and regulatory authorities to build order and thus to exert control - over the early development of regenerative medicine. Here, stem cell medicine gets normalized through assimilating the norms of clinical knowledgemaking: for this reason the translational model advanced by the ISSCR has been rightly dubbed a «cells-as-drugs $»^{23}$ approach. In this framing, regenerative medicine becomes at the same time entrenched in a narrative of ethical and regulatory oversights featuring the scientific community, professional bioethics and state agencies as exerting epistemic vigilance on the translation of stem cell science into medical applications.

In the coming section, I will analyze a substantially different approach to stem cell 
translation, proposed by the International Cellular Medicine Society in roughly the same years as the ISSCR.

\section{ICMS: standard setting for the naturalization of stem cell medicine}

The International Cellular Medicine Society is a non-profit international medical association that brings together physicians and researchers from thirty-five countries with a shared interest in advancing "point-of-care cell-based therapies $»^{25}$ by means of autologous stem cell transplants. The ICMS also describes itself in its website as a "standards organization that produced the first ever set of guidelines for the practice of cell-based medicine $\gg^{26}$. Those guidelines enact a completely different translational model than ISSCR's cells-as-drugs framing, one that is actually backed by overt adversarial intentions - as testified by the content of an open letter of ICMS' director available on the society's website and reading as follows:

« The ICMS will not stand by to allow the ISSCR or any other entrenched interest to discredit all stem cell therapies. In order to halt these vicious attacks, we believe that a set of international standards are needed to ensure patient safety and to help this field develop in the direction of responsible medical practice $\aleph^{27}$.

Guidance documents - adopted by the ICMS between 2009 and 2010 - focus exclusively on autologous adult stem cell transplants of minimally manipulated cells. The latter are conceptualized as being part of the patient's body and « represent the ability of the body to heal itself $»^{28}$. In this sense, the therapeutic essence of stem cells is thus naturalized and, at the same time, it comes to constitute the basis for a right of patients to use a healing material that is their own. The naturalization of stem cell therapy, as opposed to the normalization of clinical translation promoted by the ISSCR, amounts at an ontological categorization of stem cells as natural parts of patient's body. This ontological move implies an ad hoc epistemic and regulatory architecture for knowledge certification - one that departs starkly from the standards of regulatory knowledge supported by the ISSCR.

The architrave of the guidance set forth by ICMS is its support of "legitimate medical innovation outside the context of clinical trials $»^{29}$ based on two preliminary assumptions: first, the explicit endorsement of therapeutic freedom as formulated in claims affirming that « an informed patient has the right to access innovative therapies », or that "[i]n consultation with a qualified physician, a patient must be empowered to make an informed healthcare decision $»^{30}$; and second, the idea that "autologous adult stem cells is the practice of medicine and, as such, is subject to the laws and regulations that cover the practice of medicine $»^{31}$. The patient-doctor relationship and the relationship of patients with their bodily material are thus framed as exclusive ones, whereby undue regulatory interference, for example by State agencies or expert communities, is in principle unjustified.

The activity of regulatory agencies and of the scientific community against the practice of 
unproven stem cell medicine is perceived as bearing diverging ends with respect to the therapeutic rights of patients and to the exercise of the medical profession. The quotes above instantiate the refusal of what we might want to call regulatory paternalism. Paternalism, in general, means interference with a person's will justified by the assumption that this interference will benefit that person in some way or prevent harm for occurring to her. There are numerous contexts where paternalistic intervention may occur, and numerous versions of paternalistic interventions $^{32}$, but health care is definitely one of the most prominent areas where paternalism is discussed. Typically, medical paternalism refers to physicians withholding important information about a patient, allegedly, to protect that patients from harm that that information may provoke. But in our case, the ICMS clearly constructs regulatory and epistemic norms regulating stem cell medicine as a form of undue interference with people's therapeutic freedom, and indeed a paternalistic one, given the motivation for such arrangements is the protection of final users. In this instance, paternalist allegations are not directed to the practicing doctor, but to biomedical researchers and governmental agencies who impose their views on how innovative practices should be traded against the will of patients to access the kind of therapy they prefer.

One may want to argue that such a conceptualization of therapeutic rights as opposed to regulatory paternalism is typical of health care systems where, like it is the case in the US, "physicians often work in fee-forservice settings, and they become allies with their patients in a consumerist demand for more patient autonomy in purchasing services $\gg{ }^{33}$. As a matter of fact however, unproven stem cell therapies where commercialized also in Europe $^{34}$ and in particular in Italy - a country that enjoys a national health care service covering all citizens almost for free - under controversial interpretations of the notion of compassionate use and of the hospital exemption rule that regulates $\mathrm{it}^{35}$. This testifies that the naturalization narrative, with all its load of ethical and regulatory assumptions, can spread across different models of health care and that it is probably sustained as much by commercial attitudes as by patients' eagerness to access new therapies.

\section{Risk and the re-making of regulatory ontologies by ICMS}

Constructing stem cell medicine outside conventional modalities of knowledge production requires a complex exercise in remaking medical and regulatory ontologies. This effort on the part of the ICMS relies primarily on the introduction of a grading system for stem cell treatments and on the definition of ready-to-use risk assessment criteria.

Through to the ICMS guidelines, attempted cell-based procedures need to be assessed according to a "clinical staging" classification ${ }^{36}$. In a not too hidden effort at mimicking the epistemic structure of stepwise clinical trials, clinical staging includes a hierarchy of steps that treatments must pass in order to be used in clinical practice. According to this schema, stem cell procedures are graded primarily as to 
the number of patients they were used for and the extent of post-use monitoring that followed the treatment. For example, cells that have never been used in humans but were used in several animal models without adverse reactions are called Early Investigational Cell Lines. These can be used on a small number of patients (five to ten) and should be monitored for at least six months for adverse reactions. If no significant complication is reported, the procedure can pass to the next step of the grading scale, meaning those cells can be considered Late Investigational Cell Lines, and can be used on a bigger group of patients (twenty to fifty). Fulfilling the requirements of previous stages is a prerequisite to move up to the next stage of the grading, all the way up to Early and Late Clinical Cell Lines (between one and threehundred patients followed up for six months) and finally to the highest, unrestricted status of Clinical Grade Cell Lines. The history of a treatment's previous uses (and thus the evidence for its current grading) is reported in a treatment registry administered by the ICMS. It is the Registry's scientific committee - composed of ICMS members - that then determines the grading of deposited lines according to the above-described criteria. Adhering to this voluntary system, stem cell doctors accept ICMS as a source of scientific accreditation and patients are allegedly assured of the safety of novel cell-based procedures. The registry is therefore a tool (epistemic and regulatory) by means of which ICMS alone uptakes all the burden of certifying the safety of stem cell reimplantation procedures. Contrary to the ISSCR framing, here the FDA and similar agencies are not considered by the ICMS as legitimate partners in stem cell innovation. Moreover, as to the relationship between doctors and patients, it is not conceptualized under conventional bioethical categories.

A point to mention here is that, being clinical staging about autologous stem cells, it is not possible to understand the expression 'cell line' in terms of direct lineage with a clonal ancestry. Since in this modality every patient receives an injection of newly established ex vivo cell batches, it is indeed inappropriate to speak of cell lines ${ }^{37}$. Moreover, the clinical staging system does not mention any specific criterion of demarcation between the controlled production of generalizable medical knowledge (i.e., the aim of proper clinical trials) and the clinical use of stem cells in medical practice: knowledge is produced - if at all - by observing the effects of clinical practice, and clinical practice is the activity from which data are collected to form the basis of knowledge and risk assessment claims $^{38}$.

This strategy is clearly alternative to ISSCR's framing, but it also relies on further classificatory elements in the ICMS guidelines. This document lays down a « risk stratification system for tissue translation »: with the aim of framing autologous stem cell therapy as bearing only minimal risks, the guidelines attempt an unprecedented classification of human tissue types. The proposed classification lumps together different tissues so that, for instance, muscle, tendon, cartilage, bone, ligament and intervertebral disc all make up the same group (called "mesodermal orthopedic tissue"). The idea behind this classificatory effort is to link bodily 
sites to ready-made risk assessment criteria. So, for instance, cells extracted from and re-injected in the same tissue group bear only minimal risk, whereas attempting to transplant a cell type that belongs to a group into a bodily site that belongs to another implies more than minimal risks. Far from reflecting naturally occurring categories, this classification is mobilized to accommodate favorable risk profiles for practiced stem cell procedures. Anatomical categories are thus rearranged in a way that fits assumptions about the safety of practicing stem cell therapists. Risk assessment here is, again, naturalized according to a physiological classification, in an effort to project order onto the medical practice of cell therapy. This whole classificatory exercise thus relies on the mutually reinforcing construction of unconventional criteria of knowledge-making and ready-to-use risk assessment parameters: in this way, the medical representation of the human body gets remade to become liable to stem cell medicine. By the same token, criteria of clinical risk are spelled out according to such new ontologies, so that the practice of stem cell medicine can be constructed outside the epistemic and regulatory territory of conventional forms of knowledge-making and risk assessment. This framing constructs the patient as entitled to pursue her therapeutic choices with her "own" cells, following the advice of the doctor she chose, without the interference of regulatory agencies. Again, as in the previous case, ICMS' guidance relies on a pragmatic repertoire of practices and classifications to make a given version of cell medicine possible, namely in the form of a free commercial transaction between patient and doctor.

\begin{tabular}{|l|l|l|}
\hline & ISSCR & ICMS \\
\hline General framing & $\begin{array}{l}\text { Normalization: cells-as- } \\
\text { drugs. }\end{array}$ & $\begin{array}{l}\text { Naturalization: cells as "own" } \\
\text { body parts. }\end{array}$ \\
\hline \multirow{3}{*}{ Scientific validation } & $\begin{array}{l}\text { Peer review. } \\
\text { CCTs. } \\
\text { EBM. }\end{array}$ & $\begin{array}{l}\text { Clinical staging. } \\
\text { Risk stratification system. }\end{array}$ \\
\hline \multirow{3}{*}{ Patients } & $\begin{array}{l}\text { Regulatory authorities. } \\
\text { Dedicated law*. } \\
\text { Voluntary guidelines. }\end{array}$ & $\begin{array}{l}\text { Voluntary guidelines. } \\
\text { No regulatory paternalism. }\end{array}$ \\
\hline & $\begin{array}{l}\text { Epistemic vigilance: } \\
\text { patients protected by experts } \\
\text { and authorities. }\end{array}$ & $\begin{array}{l}\text { "Own" cells. } \\
\text { Commerapeutic freedom. }\end{array}$ \\
\hline
\end{tabular}

\section{Table 1. Main features of disjunctive framings of stem cell translation.}

CCTs: controlled clinical trials; EBM: evidence-based medicine.

* a dedicated legal regime is not demanded, but neither excluded a priori by the ISSCR. 


\section{Conclusion}

In this paper I showed that the constitution of human bodily elements as a new kind of materia medica is presently taking shape as a scientific controversy. Especially in this early translational phase, there appears to be multiple models of regenerative medicine competing to establish their respective framings as the benchmark for the future development of the field: the guidelines issued by scientific stakeholders mobilize radically different imaginaries ${ }^{39}$ of the present and the future of regenerative medicine (see Table 1). Those framings are disjunctively organized around contrasting epistemic and ontological assumptions. On the epistemic side, the two scientific societies embrace two different models of knowledge making and validation. On the one hand, the ISSCR espouses a model of normalization for the scientific development of stem cell medicine - one that projects existing standardized modalities of knowledge production on novel therapeutic entities like stem cells. On the contrary, the ICMS refuses this epistemic norms and elaborates ad hoc criteria of clinical validity for the practice of autologous stem cell medicine. From an ontological point of view, the ISSCR defines cells as drugs whereas the ICMS constructs stem cells as bodily elements thus naturalizing their therapeutic potential as well as the criteria that allow their safety evaluation. Those transactions reveal that the development of a new therapeutic approach requires conspicuous efforts of boundary construction between different epistemic commitments and, indeed, the definition of a specific ontological framework for the new medical entities.
As a matter of fact those epistemic and ontological constructions determine the respective regulatory outlook of the two societies. From a regulatory standpoint, ISSCR suggests an epistemic alignment between scientists developing stem cell therapies, IRBs and ERBs and regulatory oversight agencies, whereas the ICMS contrasts this form of oversight as an instance of regulatory paternalism.

The ISSCR sees the patient as an epistemically vulnerable party that the scientific community has the duty to inform, and possibly warn about unproven therapeutic options. In the naturalized framing, instead, cells are conceived as a patient's body parts thus enabling their use on the basis of a natural entitlement as well as of an individual right of therapeutic freedom. Given these premises and given the prevalent commercial character of the kind of treatment offered to patients under this framing in favorable jurisdictions, the therapeutic encounter acquires here the character of a market transaction between providers and consumer of healthrelated services. However, this consumerist attitude, as I said, is also fed by a growing impatience on the side of consumers to access innovative therapies as soon as possible.

The translational models presented in this paper testify that the governance of biotechnology relies on standardization and classificatory practices attempting to bring order around the unsettling presence of new biotechnological $\operatorname{artifacts}^{40}$. More specifically, our analysis showed that the discursive and pragmatic articulation of a space of action - for both practitioners and patients - is necessary to 
make a given framing of regenerative medicine possible. To the extent that regenerative medicine constructs body parts as medicaments, contentious epistemic and regulatory practices are called into question in order to realize this far from obvious ontological leap. This results in the presence of contrasting interpretations about how stem cells should be translated to the clinic - one drawing on normalization and the other on naturalization as discursive-pragmatic governance resources.

Indeed, regenerative medicine will keep on evolving in the next future as new scientific knowledge will accumulate and new clinical practices will be experimented. Arguably, controversy will occur as actors try to build professional cohesion and feed public trust in their scientific activities. As a consequence, following the trajectory of these translational models as they are proposed, contested, defeated or supported by scientific actors and regulatory authorities will be key to a critical appraisal of the regulatory regime that is stabilizing this bursting domain of scientific innovation.

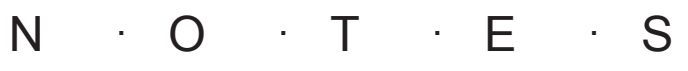

1. Voir infra, Daniel Boy, «Les réprésentations sociales des thérapies innovantes ».

2. Voir infra, NathalieSchiffino, « Les thérapies innovantes au prisme de l'évaluation des politiques publiques et de l'appréhension du risque ».

3. H. Gottweis, B. Salter, C. Waldby, The global politics of human embryonic stem cell science: regenerative medicine in transition. New York, NY, Palgrave Macmillan, 2009.

4. A. Blasimme, B. Schmietow, G. Testa, « Reprogramming potentiality: the co-production of stem cell policy and democracy ». American Journal of Bioethics. 13(1) : 30-2; 2013.

5. K. Hug and G. Hermerén (eds.), Translational Stem Cell Research: Issues Beyond the Debate on the Moral Status of the Human Embryo. Springer, 2011.

6. S. Jasanoff S. States of Knowledge: The Coproduction of Science and the Social Order. New York, NY, Routledge, 2004.

7. A. S. Daar, H. L. Greenwood, « A proposed definition of regenerative medicine ", Journal of Tissue Engineering and Regenerative Medicine, 1(3) : $181 ; 2007$.

8. Voir supra, Florence Taboulet, « Les medicaments de thérapie innovante : quelles spécificités en droit pharmaceutique?».

9. F. R. Appelbaum, "Hematopoietic-Cell Transplantation at $50 »$, New England Journal of Medecine, 357 (15) : 1472-1475; 2007.

10. K. Takahashi, K. Tanabe, M. Ohnuki et al., « Induction of pluripotent stem cells from adult human fibroblasts by defined factors », Cell., 131(5) : 861-72 ; 2007.

11. Although biologically similar to other pluripotent stem cells, at present reprogrammed cells might 
have epigenetic and genetic alterations (due to the reprogramming process) that could prevent their clinical use.

12. A. I. Caplan, «Adult Mesenchymal Stem Cells for Tissue Engineering Versus Regenerative Medicine », Journal of Cellular Physiology, 213 (2) : 341-347 ; 2007.

13. Pashuck, E. Thomas and M. M. Stevens, « Designing Regenerative Biomaterial Therapies for the Clinic », Science Translational Medicine, 4 (160): 160sr4-160sr4; 2012.

14. D. B. Saris, J. Vanlauwe, J. Victor, et al., "Characterized Chondrocyte Implantation Results in Better Structural Repair When Treating Symptomatic Cartilage Defects of the Knee in a Randomized Controlled Trial Versus Microfracture », The American Journal of Sports Medicine, 36 (2) : 235-246 ; 2008. 15. P. Stroemer, « Development of a human neural stem cell line for use in recovery from disability after stroke », Frontiers in Bioscience, 13 (13) : $2290 ; 2008$. 16. S. Timmermans and M. Berg, The Gold Standard: The Challenge of Evidence-Based Medicine and Standardization in Health Care. Philadephia, Temple University Press; 2003; V. Tournay, « Collecter, centraliser, circuler, contraindre et répéter : cinq modalités pour standardiser les connaissances et les pratiques en matière d'innovation médicale», Quaderni 58(1) : 33-45 ; 2005 ; P. Keating, A. Cambrosio A. « Cancer clinical trials: the emergence and development of a new style of practice », Bullettin of the History of Medicine, 81(1) :197-223 ; 2007; P. Keating, A. Cambrosio A. Cancer on Trial: Oncology As a New Style of Practice. Chicago, IL, University of Chicago Press ; 2012.

17. H. Chen, H. Gottweis, « Stem Cell Treatments in China: Rethinking the Patient Role in the Global Bio-Economy », Bioethics, doi: 10.1111/j.14678519.2011.01929.x $2011 ; 2011$.
18. This judgement obviously does not extend to bone marrow transplantations for hematologic disorders that are already well established practices in current medicine.

19. ISSCR «Guidelines for the Clinical Translation of Stem Cells» p. 4. Available at http://www.isscr.org/ home/publications/ClinTransGuide (last accessed: December 2012).

20. The task force was composed of an international panel of stem cell scientists, clinicians, bioethicists and regulatory offcicials, see I. Hyun, O. Lindvall O, L. Ährlund-Richter et al., « New ISSCR Guidelines Underscore Major Principles for Responsible Translational Stem Cell Research », Cell Stem Cell, 3(6) : 607-9; 2008.

21. ISSCR, op. cit. p. 4.

22. S. Jasanoff, "Ordering life: law and the normalization of biotechnology » Notizie di Politeia, 17(62) : 34-50; 2001.

23. A. Cambrosio, Alberto, P. Keating, T. Schlich and G. Weisz, « Regulatory objectivity and the generation and management of evidence in medicine », Social Science \& Medicine 63 (1) : 189-199; 2006.

24. A. Webster A, C. Haddad, C. Waldby, Experimental heterogeneity and standardisation : Stem cell products and the clinical trial process. BioSocieties. 6 : 401-19; 2011.

25. See ICMS website at http://www. cellmedicinesociety.org/ (last accessed, December 2012)

26. Ibid.

27. See ICMS Guidance available at http://www. cellmedicinesociety.org/icms-guidelines; last accessed December 2012.

28. Ibid.

29. Ibid.

30. Ibid.

31. ibid. 
32. From a conceptual point of view, philosophers tend to distinguish between various versions of paternalism (e.g. hard v soft, broad v narrow, weak v strong) according to the extent of the interference that a given account of paternalism is prone to justify. A seminal contribution to this debate can be found in $\mathrm{J}$. Feinberg, «Legal Paternalism », Canadian Journal of Philosophy, 1,1 (September); 1971. For an overview on the theme see D. Scoccia, Paternalism, in The International Encyclopedia of Ethics, 2013, doi : 10.1002/9781444367072.wbiee233.

33. R. Alta Charo, Politics, Progressivism, and Bioethics, in J. D. Moreno and S. Berger (eds), Progress in Bioethics, Cambridge, MA, The MIT Press ; 2012, p. 50.

34. A. Blasimme, « Terapie cellulari "sperimentali”: il caso Carrer », available at http://www.scienzainrete. it/contenuto/articolo/terapie-cellulari-sperimentalicaso-carrer. In italian. Last accessed December 2012. 35. A. Blasimme, 2012. «Regenerative Medicine and the Governance of Stem Cell Innovation ». Doctoral Thesis, European School of Molecular Medicine (SEMM) - Università degli Studi di Milano. http://air. unimi.it/handle/2434/214610.

36. The stem cell procedures under discussion here, as I recalled above, are autologous adult stem cell injections only.

37. The expression 'cell lines' conveys the idea that cells belonging to the same "line" behave similarly - a feature that would allegedly confer biological consistency to the clinical staging categories. However, the burden of proving that the same cell type will act in the same manner in autologous reimplantation procedures in different patients is on the shoulder of practitioners, and it is a matter of statistical inference no less than it is in the case of heterologous cell therapies with bona fide clonal cell lines (or of any drug). As a consequence, clinical staging lacks justification in assuming that cells will behave similarly in all patients just because they belong to the same type. As a matter of fact, according to the epistemic standards of current medicine, only a clinical trial could resolve the issue of safety and efficacy of the procedures proposed by the ICMS - but clinical trials are exactly what this regulatory edifice attempts to avoid.

38. The demarcation of knwoledge-making and clinical practices is not only an epistemic one that separates the systematic production of data from the often messy provision of medical care. It is also one of the bioethical hallmarks of research participants protection that emerged in the US in the Seventies after a series of scandals (see R. R. Faden, T. L. Beauchamp, N. M. P. King, A history and theory of informed consent. New York and Oxford, Oxford University Press, USA; 1986). It has to be noticed however, that the conceptual line that separates research from treatment is being blurred at least in some innovative areas of health care like comparative effectiveness research (see N. E. Kass, R. R. Faden, S. N. Goodman, P. Pronovost, S. Tunis, T. L. Beauchamp, « The Research-Treatment Distinction : A Problematic Approach for Determining Which Activities Should Have Ethical Oversight », Hastings Center Report 43 (s1) : S4-S15 ; 2013).

39. S. Jasanoff, S.H. Kim, « Containing the atom: sociotechnical imaginaries and nuclear power in the United States and South Korea », Minerva. 47(2):119-46; 2009.

40. V. Tournay, « De la bioéthique à l'action publique en matière de biotechnologies : la production des thérapies cellulaires ", Cahiers internationaux de sociologie, 121(2) : $265 ; 2006$. 


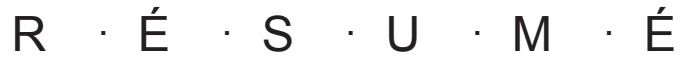

Transposer les cellules souches en clinique : sociétés savantes et structuration de la médecine régénérative Dans cet article, l'auteur présentera deux corpus de lignes directrices professionnelles établies par deux sociétés savantes œuvrant dans le domaine de la médecine régénérative utilisant des cellules souches : la «Société internationale pour la recherche sur les cellules souches » (ISSCR) et la " Société internationale de médecine cellulaire » (ICMS). Ces lignes directrices présentent des points de vue divergents sur la façon dont les cellules souches devraient être utilisées en thérapie pour les patients. Elles démontrent l'existence de postures alternatives pour l'encadrement de l'utilisation clinique de ces cellules en s'appuyant sur des hypothèses ontologiques, épistémologiques, éthiques et réglementaires différentes. Ces deux interprétations radicalement opposées sur la façon dont les cellules souches devraient être transposées pour des applications cliniques, s'ancrent respectivement sur des postures narratives soit de normalisation soit de naturalisation. Ces dernières sont envisagées comme des ressources pragmatiques- discursives permettant d'articuler le présent et l'avenir de la médecine régénérative.

S'intéresser aux différentes voies de normalisation de la médecine régénérative constitue une véritable opportunité pour une compréhension approfondie de la constitution même des options du passage à l'utilisation clinique des cellules souches. En effet, dans le futur, la médecine régénérative va continuer à évoluer puisque de nouvelles connaissances scientifiques s'accumuleront et de nouvelles pratiques cliniques seront expérimentées. On peut même soutenir que la controverse sera plus importante dans la mesure où les acteurs essaient de construire la cohésion professionnelle et de nourrir la confiance du public dans leurs activités scientifiques. En conséquence, suivre la trajectoire de ces modèles translationnels tels qu'ils sont proposés, contestés, rejetés ou soutenus par les acteurs scientifiques et les autorités réglementaires sera fondamental pour permettre une évaluation critique des régimes d'encadrement qui stabiliseront ce domaine émergent de l'innovation scientifique.

\begin{abstract}
In this article I will illustrate two prominent bodies of professional guidance issued by two different scientific societies active in the field of stem cell-based regenerative medicine: the International Society for Stem Cell Research (ISSCR) and the International Cellular Medicine Society (ICMS). These guidelines offer strikingly diverging accounts of how stem cells should be translated into therapies for patients, thus demonstrating the existence of alternative framings of clinical translation relying on diverging ontological, epistemic, ethical and regulatory assumptions. These two radically contrasting interpretations of how stem cells should be translated into clinical applications draw, respectively, on a normalization and on a naturalization narrative as discursive-pragmatic resources to articulate the present and the future of regenerative medicine.
\end{abstract}

Looking at the different routes towards standardization of regenerative medicine provides a timely opportunity for a deeper understanding of the very constitution of translational options. Indeed, regenerative medicine will keep on evolving in the next future as new scientific knowledge will accumulate and new clinical practices will be experimented. Arguably, more controversy will occur as actors try to build professional cohesion and feed public trust in their scientific activities. As a consequence, following 
the trajectory of these translational models as they are proposed, contested, defeated or supported by scientific actors and regulatory authorities will be key to a critical appraisal of the regulatory regimesthat is stabilizing this bursting domain of scientific innovation. 